\title{
Eating Quality of Carrots (Daucus carota L.) Grown in One Conventional and Three Organic Cropping Systems over Three Years
}

\author{
Vibe Bach, Ulla Kidmose, Hanne L. Kristensen, and Merete Edelenbos* \\ Department of Food Science, Aarhus University, Kirstinebjergvej 10, DK-5792 Aarslev, Denmark
}

ABSTRACT: The eating quality of carrots (Daucus carota L.) was investigated to evaluate the impact of cropping systems (one conventional and three organic systems) and growing years (2007, 2008, and 2009) on root size, chemical composition, and sensory quality. The content of dry matter, sugars, polyacetylenes, and terpenes as well as the sensory quality and root size were related to the climate during the three growing years. A higher global radiation and a higher temperature sum in 2009 as compared to 2007 and 2008 resulted in larger roots, higher contents of dry matter, sucrose, total sugars, and total polyacetylenes, and lower contents of terpenes, fructose, and glucose. No differences were found between conventional and organic carrots with regard to the investigated parameters. This result shows that organically grown carrots have the same eating quality as conventionally grown carrots, while being produced in a more sustainable way.

KEYWORDS: Daucus carota L., organic, conventional, polyacetylenes, terpenes, sugar, dry matter, sensory descriptive analysis, climate

\section{INTRODUCTION}

Carrot (Daucus carota L.) is an important food crop with a low sensitivity to cropping system, ${ }^{1}$ which makes it well-suited for organic production. Carrots are consumed both raw and cooked or processed into frozen products or juice. The eating quality of carrots is determined by cultivar, fertilization, geographical location, and climate. ${ }^{2-5}$ The cultivar and the year-to-year variation in climate has a bigger influence on the quality of carrots than the cropping system. ${ }^{6}$ Paoletti et al. ${ }^{7}$ also reported that year had a greater effect on carrot quality than conventional and organic cropping, but they did not take variation in climate into consideration.

Consumers expect organic foods to be healthier and safer than conventional foods and to taste better, but the scientific literature is contradictionary and it has been shown that there is no difference in eating quality between organic and conventional foods. ${ }^{6,8,9}$ A recent meta-analysis, however, showed that organic foods have higher contents of antioxidants and lower contents of cadmium, nitrate, nitrite, and pesticide residues than the similar conventional food. ${ }^{10}$ Only a few studies have compared the sensory quality of conventionally and organically grown carrots under comparable conditions. ${ }^{7,11}$ Haglund et al. ${ }^{12}$ found that organically grown carrots were more bitter and had less carrot flavor than conventional carrots, but the results were presented as averages across several cultivars and growing sites. Studies comparing chemical composition of conventionally and organically grown vegetables have mainly focused on nutrients, ${ }^{8,9,13}$ and selected secondary metabolites such as carotenoids, polyacetylenes, and phenolic acids. ${ }^{6,14,15}$ However, studies are lacking which compare the eating quality of conventionally and organically grown vegetables under comparable field conditions. ${ }^{11}$

In organic vegetable production, synthetic pesticides are banned and the type and intensity of fertilization is restricted with the aim of making less impact on the environment. Organic vegetable production relies on fertilization methods based on organic matter or mobilization via the use of nitrogenfixing plants. ${ }^{1}$

The sensory quality of carrots is determined by its content of primary and secondary metabolites. Especially cultivar and geographical location and thus soil type and climate play a major role in the chemical composition of carrots. ${ }^{4,16}$ It is wellknown that the source of nitrogen may influence nitrogen availability, ${ }^{6,9}$ and thus indirectly dry matter (DM) content and the sugar metabolism, ${ }^{17,18}$ and thereby the taste and texture of the carrot. Besides this, temperature and light during growth influence the weight, length, and shape of the carrot root, ${ }^{3,19-21}$ and it can cause a large variation in root size between growing years. $^{22}$

Aliphatic C17 polyacetylenes of the falcarinol-type are widespread in the Apiaceae family. ${ }^{23,24}$ In carrots, falcarinol $(\mathrm{FaOH})$, falcarindiol $(\mathrm{FaDOH})$, and falcarindiol-3-acetate (FaDOAc) are the main polyacetylenes identified, ${ }^{23}$ of which especially falcarindiol contributes to a bitter taste of carrots. ${ }^{25}$ Terpenes constitute $\geq 98 \%$ of the total volatile fraction of carrots mainly being mono- and sesquiterpenes, ${ }^{26-28}$ where especially the monoterpenes are responsible for the aroma and flavor of carrots. ${ }^{27,29}$

The aim of the present study was to investigate the quality differences between carrots grown in one conventional and three organic cropping systems during three consecutive years on the same geographical location. Every year the root size and the contents of DM, sugars, terpenes, and polyacetylenes were determined and the sensory quality assessed by a trained sensory panel. The results on cropping systems and growing years were related to data on chemical composition and sensory quality as well as to the climatic conditions.

Received: June 26, 2015

Revised: October 6, 2015

Accepted: October 8, 2015

Published: October 29, 2015 
Table 1. Production of Carrots in the Conventional and Organic Cropping Systems ${ }^{a}$

\begin{tabular}{|c|c|c|c|c|}
\hline cropping system & C conventional & O1 organic & O2 organic & O3 organic \\
\hline autumn soil cover & no soil cover & no soil cover & undersown mixture $^{b}$ & undersown mixture ${ }^{c}$ \\
\hline nutrient supply & NPK fertilizer & import of conventional pig slurry & mineralization of mixture $^{b}$ & mineralization of mixture ${ }^{c}$ \\
\hline $\mathrm{N}$ addition $\left(\mathrm{kg} \mathrm{N} \mathrm{ha}^{-1}\right)$ & 120 & 56 & 0 & 0 \\
\hline use of synthetic pesticides & yes & no & no & no \\
\hline
\end{tabular}

${ }^{a}$ See Thorup-Kristensen et al. ${ }^{1}$ for details on cropping systems. ${ }^{b}$ Legume/nonlegume mixture of Anthyllis vulneraria L., Medicago lupulina L., Trifolium repens L., Trifolium pratense L., and Lolium perenne L. was undersown in oats the year before and incorporated into the soil before carrots were sown. ${ }^{c}$ Legume/nonlegume mixture of Sanguisorba minor Scop. and Lotus corniculatus L. was undersown in oats the year before. The following year, two-thirds of the mixture was incorporated into the soil in strips before carrots were sown, the rest being left as an intercrop grown together with the carrots.

Table 2. Production Parameters and Root Size of Carrots ${ }^{a}$

\begin{tabular}{|c|c|c|c|c|}
\hline & \multicolumn{3}{|c|}{ year } & \multirow[b]{2}{*}{ significance level $^{b}$} \\
\hline & 2007 & 2008 & 2009 & \\
\hline \multicolumn{5}{|l|}{ production parameters } \\
\hline days to harvest ${ }^{c}$ & 133 & 131 & 139 & - \\
\hline $\begin{array}{l}\text { days stored at } 1{ }^{\circ} \mathrm{C} \\
\text { root size }\end{array}$ & \multicolumn{3}{|c|}{ root size } & - \\
\hline root weight $(\mathrm{g})$ & $112 \mathrm{~b}^{d}(100-130)$ & 99 c $(87-113)$ & 126 a $(106-149)$ & $P \leq 0.001$ \\
\hline root length $(\mathrm{cm})$ & $16.9 \mathrm{~b}(15.6-17.7)$ & 15.9 c $(14.0-16.9)$ & 17.9 a $(17.0-19.1)$ & $P \leq 0.001$ \\
\hline cylindricity $^{e}\left(\mathrm{~g} / \mathrm{cm}^{3}\right)$ & $0.73 \mathrm{a}$ & $0.71 \mathrm{a}$ & $0.68 \mathrm{~b}$ & $P \leq 0.001$ \\
\hline
\end{tabular}

${ }^{a}$ The data on root size is presented as means of the four cropping systems with 10 replicate roots from each system $(N=40)$. Ranges are given in parentheses. ${ }^{b}$ Significance levels: - , not determined. ${ }^{c}$ Days from sowing to harvest. ${ }^{d}$ Means followed by different letters in the same row are significantly different according to Tukey's honest significant difference test at $P=0.05 .{ }^{e}$ Cylindricity is calculated as root weight $(\mathrm{g}) /\left[\pi^{*}(\right.$ root radius $(\mathrm{cm}))^{2}$ root length $\left.(\mathrm{cm})\right]$ according to Bleasdale and Thompson. ${ }^{31}$

\section{MATERIALS AND METHODS}

Reagents and Chemicals. Ultrapure water was made by an Elgastat Maxima Analytica Water Purification System (Elga LabWater, Marlow, United Kingdom). Authentic standard of glucose was supplied by Merck Chemicals (Darmstadt, Germany), and standards of fructose and sucrose were from Sigma-Aldrich (St. Louis, MO). Sodium hydroxide $(\mathrm{NaOH})$ and anhydrous $\mathrm{Na}_{2} \mathrm{SO}_{4}$ were purchased from Merck Chemicals (Darmstadt, Germany), and HPLC-grade ethyl acetate $(\mathrm{EtOAc})$ and acetonitrile $(\mathrm{MeCN})$ were from Sigma-Aldrich (St. Louis, MO). All HPLC-eluents were filtered through $0.45 \mu \mathrm{m}$ Minisart SRP 25 filters (Bie \& Berntsen, Rødovre, Denmark) and degassed by ultrasound for 20 min before use. Authentic standards of $\mathrm{FaOH}, \mathrm{FaDOH}$, and $\mathrm{FaDOAc}$ were isolated from carrots following the procedure of Kidmose et al. ${ }^{4}$ Authentic aroma reference compounds of $\alpha$-phellandrene, $\beta$-myrcene, $\alpha$-terpinene, $\rho$-cymene, $\beta$-caryophyllene, and $\alpha$-humulene were obtained from Fluka Chemie $\mathrm{GmbH}$ (Buchs, Switzerland), $\alpha$-pinene, camphene, $\beta$-pinene, sabinene, limonene, $\beta$ phellandrene, and $\gamma$-terpinene from Sigma-Aldrich (St. Louis, MO), $\alpha$ thujene and $\beta$-farnesene from Wako Chemicals Ltd. (Tokyo, Japan), terpinolene from Carl Roth GmbH (Karlsruhe, Germany), and $\gamma$ bisabolene from TCI Tokyo Organic Chemicals Ltd. (Tokyo, Japan). $\beta$-Bisabolene was synthesized using the method of Crawford et al. ${ }^{30}$

Production of Carrots. Carrots (Daucus carota L. cv. Bolero) were grown in four cropping systems: one conventional (C) and three organic systems (O1, O2, and O3) in the years 2007, 2008, and 2009. All carrots were grown at the Department of Food Science, Aarhus University, Research Centre Aarslev, Denmark $\left(10^{\circ} 27^{\prime} \mathrm{E}, 55^{\circ} 18^{\prime} \mathrm{N}\right)$ in a sandy loam soil (Typic Agrudalf) with a $0-0.5 \mathrm{~m}$ soil layer containing $1.0 \%$ carbon, $13 \%$ clay, $15 \%$ silt, and $70 \%$ sand. The $\mathrm{pH}_{\mathrm{CaCl} 2}$ was 6.7; the content of phosphorus was $23 \mathrm{mg} \mathrm{kg}^{-1}$, and that of potassium $115 \mathrm{mg} \mathrm{kg}^{-1}$ (P was extracted with $0.5 \mathrm{M} \mathrm{NaHCO}_{3}$ and $\mathrm{K}$ with $\mathrm{CH}_{3} \mathrm{COONH}_{4}$ ). All fields were managed according to organic practice 10 years prior to the setup of the experiment in Autumn 2006. ${ }^{1}$ Carrots were grown following oats as part of an 8-year crop rotation system including a number of vegetables and cereals. The experiment was a randomized complete block design with three field replicates. Table 1 gives an overview of the four cropping systems used for the carrots. The cropping systems varied in nutrient supply and pest management. Pesticides and nutrients in the form of inorganic NPK fertilizer were applied in the conventional system (Table 1). In the $\mathrm{O} 1$ system, nutrients were imported pig slurry, and in the $\mathrm{O} 2$ and O3 systems, an autumn crop of undersown legume/nonlegume mixture was incorporated into the soil in the early spring as green manure. In the $\mathrm{O} 3$ system, parts of the undersown mixture were left to grow as an intercrop between the rows of carrots (Table 1). A detailed description of the experimental design and the cropping systems including pest management, fertilization, and tillage operations is given in Thorup-Kristensen et al. ${ }^{1}$ Over the growing season the carrots were irrigated when precipitation deficits increased above $30 \mathrm{~mm}$. In all years carrots were harvested in the first week of October when taproots were fully mature. After harvest the carrots were stored at 1 ${ }^{\circ} \mathrm{C}$ and $98 \%$ relative humidity to avoid early decay and dehydration. Carrots were analyzed between 22 and 44 days after harvest (Table 2). The field replicates were used as true triplicates in the analyses.

Climate Monitoring. The air temperature $2 \mathrm{~m}$ above ground and global radiation were measured daily during the growing period from May to October on the national weather station at Research Centre Aarslev. The mean air temperature is given as monthly averages and as averages over growing year. The temperature sum is calculated as the sum above $0{ }^{\circ} \mathrm{C}$. Global radiation is given as total per month and as total over growing year.

Sample Preparation. A representative sample of $10 \mathrm{~kg}$ of carrots with no visible defects was taken from each field replicate for analyses. Carrots were washed, and a subsample of 50 of the most representative roots in the size range $75-150 \mathrm{~g}$ was taken for analyses. Root weight, root length, and upper root diameter were measured on 10 randomly selected carrots from the subsample. From these values root cylindricity was calculated as described in Bleasdale and Thompson ${ }^{31}$ $\left(\right.$ cylindricity $=\operatorname{root}$ weight $(\mathrm{g}) /\left[\pi^{*}(\text { root radius }(\mathrm{cm}))^{2 *}\right.$ root length $(\mathrm{cm})])$. Carrots with a cylindrical shape had a cylindricity value close to 1 , while roots with a conical shape had a value close to $0 .^{22}$ The 50 carrots were then manually peeled (approximately $0.65-1.00 \mathrm{~mm}$ of the periderm was removed) and trimmed $(2 \mathrm{~cm}$ of the tip and $2 \mathrm{~cm}$ of the top were removed), cut into sticks of $2 \times 2 \times 20 \mathrm{~mm}$ on a food processor (Robot Coupe CL50, Vincennes, France), and carefully mixed. Samples from each field replicate were taken for immediate 
analyses of DM, polyacetylenes, terpenes, and sensory quality. A subsample of $75 \mathrm{~g}$ was frozen in liquid nitrogen and kept at $-24{ }^{\circ} \mathrm{C}$ until later for analysis of sugars.

Dry matter. The DM content was determined by weighing carrots sticks before and after drying in a ventilated oven (Lytzen A/S, Herlev, Denmark) at $80{ }^{\circ} \mathrm{C}$ for $20 \mathrm{~h}$.

Extraction and Analysis of Sugars. Free sugars were extracted with water and identified and quantified by high-performance anion exchange chromatography (HPAEC) following the method of Kreutzmann et al. ${ }^{32}$ Frozen carrot sticks were homogenized in ultrapure water, and free sugars were extracted from $2 \mathrm{~g}$ of carrot puree with $50 \mathrm{~mL}$ of ultrapure water at room temperature for $3 \mathrm{~h}$, filtered (0.45 $\mu \mathrm{m}$ AcetatePlus Cameo filter (Bie \& Berntsen, Rødovre, Denmark)), and diluted to $50 \mathrm{~mL}$ with ultrapure water. Extracted sugars were analyzed on a Dionex series 300DX ion chromatograph (Dionex, Sunnyvale, CA) coupled to a pulsed amperometric detector and equipped with a borate trap $(4 \times 50 \mathrm{~mm})$, an amino trap $(4 \times 50$ $\mathrm{mm})$, and a CarboPac PA10 analytical column $(4 \times 250 \mathrm{~mm})$ (Dionex, Sunnyvale, CA). Separation of sugars was done by gradient elution with $200 \mathrm{mM} \mathrm{NaOH}$ (A) and water (B) with the following elution profile: $0.0 \mathrm{~min}, 12 \% \mathrm{~A} ; 7.0 \mathrm{~min}, 15 \% \mathrm{~A} ; 13.0 \mathrm{~min}, 30 \% \mathrm{~A}$; 24.0-34.8 $\mathrm{min}, 100 \% \mathrm{~A} ; 35.0 \mathrm{~min}, 12 \%$ A. The solvent flow was 1 $\mathrm{mL} / \mathrm{min}$, and the oven temperature was $28{ }^{\circ} \mathrm{C}$. Sugars were identified by peak addition and quantified using calibration curves of authentic standards. The retention times (RT) for glucose, fructose, and sucrose were $10.5,12.1$, and 14.8 min, respectively.

Extraction and Analysis of Polyacetylenes. Polyacetylenes were extracted from fresh carrot tissue with EtOAc and identified and quantified by high-performance liquid chromatography (HPLC) using a modified method of Kreutzmann et al. ${ }^{32}$ Carrot sticks $(20 \mathrm{~g})$ were homogenized and polyacetylenes extracted with $60 \mathrm{~mL}$ of EtOAc under stirring overnight at room temperature. Extracts were filtered, and filtrates re-extracted with an additional $60 \mathrm{~mL}$ of EtOAc under stirring at room temperature for $3 \mathrm{~h}$ and filtrated again. The EtOAc extracts were combined, and water removed by stirring with $15 \mathrm{~g}$ of anhydrous $\mathrm{Na}_{2} \mathrm{SO}_{4}$ and then filtrated. The solvent was evaporated to dryness under reduced pressure, and the residue redissolved in $5 \mathrm{~mL}$ of EtOAc and then filtrated ( $0.45 \mu \mathrm{m}$ Nylon, Cameo filter (Osmoniks, Minnetonka, MN)). Extracted polyacetylenes were analyzed on a Dionex HPLC 580 series system (Dionex, Sunnyvale, CA) equipped with a diode array detector (Ultimate 3000, Dionex, Sunnyvale, CA) and a fluorescence detector (RF 2000, Dionex, Sunnyvale, CA). Separation was performed on a Luna $3 \mu$ C18(2) 100A column (150 $\mathrm{mm} \times 4.6 \mathrm{~mm}$ i.d., particle size $3.0 \mu \mathrm{m}$, Torrance, Phenomenex, $\mathrm{CA}$ ), by elution with $\mathrm{MeCN}$ (A) and water (B) using the following elution profile: solvent gradient $0-5 \mathrm{~min}: 20 \% \mathrm{~A}, 10 \mathrm{~min} 50 \% \mathrm{~A}, 30 \mathrm{~min} 53 \%$ A, $45-50$ min $65 \%$ A, $70-72 \min 75 \%$ A, $90-95 \min 95 \%$ A $100-110$ $\min 20 \% \mathrm{~A}$. The flow rate was $1 \mathrm{~mL} / \mathrm{min}$, the oven temperature was $40{ }^{\circ} \mathrm{C}$, and the injection volume was $20 \mu \mathrm{L}$. Compounds were monitored at $205 \mathrm{~nm}$, and the UV-spectra were recorded between 200 and $450 \mathrm{~nm}$. The UV maxima and retention times for the polyacetylenes were the following: $\mathrm{FaDOH}: \mathrm{RT}=31.5, \lambda_{\max }=233$, 246, 259; FaOH: RT $=55.1 \mathrm{~min}, \lambda_{\max }=231,244,257$; FaDOAc: RT $=$ $47.5, \lambda_{\max }=233,247,260$. Polyacetylenes were identified by peak addition and quantified using calibration curves of authentic standards isolated from carrots.

Collection and Analysis of Terpenes. Terpenes were collected by dynamic headspace sampling using a modified method of Kjeldsen et $\mathrm{al}^{27}$ and Bach et al. ${ }^{33}$ Collected terpenes were identified and quantified by gas chromatography-mass spectrometry (GC-MS). Carrot sticks $(40 \mathrm{~g})$ were placed on a bed of glass globes (diameter 1.5 $\mathrm{cm}$ ) in a $250 \mathrm{~mL}$ conical flask equipped with a glass cap connected to an inlet of dry nitrogen and fitted with a stainless steel sorbent tube containing Tenax TA $(0.200 \mathrm{~g}$ of resin, mesh size $60 / 80$, C-TBP1T, Markes International Limited, Llantrisant, United Kingdom) and placed in a thermostatic incubator (Termaks 6000 Incubator, Lytzen A/S, Herlev, Denmark) at $25{ }^{\circ} \mathrm{C}$. Nitrogen was purged through the sample at a flow rate of $50 \mathrm{~mL} / \mathrm{min}$ for $30 \mathrm{~min}$, and headspace volatiles were collected on the sorbent tube. Collected volatiles were desorbed on a thermal desorption unit (Ultra-UNITY, Markes International
Limited, Llantrisant, United Kingdom) for $15 \mathrm{~min}$ at $250{ }^{\circ} \mathrm{C}$, transferred via a heated transfer line $\left(250{ }^{\circ} \mathrm{C}\right)$ to a $-10{ }^{\circ} \mathrm{C}$ cold trap (U-TIIGCP, Markes International Limited, Llantrisant, United Kingdom), and held for $3 \mathrm{~min}$ before they were desorbed at 300 ${ }^{\circ} \mathrm{C}$. Separation was performed on a GC (Finnigan TraceGC Ultra, Thermo, Waltham, MA) equipped with a split/splitless injector and a single quadrupole MS detector (Finnigan Trace DSQ Thermo, Waltham, MA). Separation was performed using a $50 \mathrm{~m} \times 250 \mu \mathrm{m}$ CP-WAX-52 CB, $0.25 \mu \mathrm{m}$ film thickness, capillary column (Varian Inc., Palo Alto, CA) using the following temperature program: a starting temperature of $35^{\circ} \mathrm{C}$ for $1 \mathrm{~min}$, increasing to $80^{\circ} \mathrm{C}$ at $1.5^{\circ} \mathrm{C} /$ min, then to $125^{\circ} \mathrm{C}$ at $1.5^{\circ} \mathrm{C} / \mathrm{min}$, and then to $220^{\circ} \mathrm{C}$ at $18{ }^{\circ} \mathrm{C} / \mathrm{min}$, and held here for $20 \mathrm{~min}$. Helium was used as carrier gas at a flow rate of $1 \mathrm{~mL} / \mathrm{min}$, and the split ratio was $1: 11$. The mass spectrometer operated in positive ion mode with an ionization energy of $70 \mathrm{eV}$. A mass scan range of 35-650 amu was applied. Terpenes suggested by the NIST mass spectral database were verified by comparison with mass spectra and retention indices of authentic reference compounds. Terpenes were quantified using external calibration curves of authentic standards ( $\beta$-pinene, $\beta$-caryophyllene, and $\beta$-ionone) run by the method described above.

Sensory Descriptive Analysis. Sensory descriptive analysis was performed by a trained sensory panel of 9 (2007), 11 (2008), and 11 (2009) assessors aged 25-60 years old. Three assessors participated all years, while six participated two out of three years. The assessors had previously been tested for their ability to discriminate and communicate sensory impressions as described in ISO 8586-1, ${ }^{34}$ and the evaluation was performed in a sensory evaluation laboratory according to international standards. ${ }^{35}$ Prior to the first analysis, a sensory profile was developed for carrot including attributes of color, aroma, flavor, taste, and texture by the assessors. The same profile was used all three years and consisted of 16 attributes, which are described in Table 3. Samples were weighed into portions of $25 \mathrm{~g}$ in plastic

Table 3. List of Sensory Attributes with Descriptions and Used Reference Samples

\begin{tabular}{|c|c|c|c|}
\hline sense & $\begin{array}{l}\text { sensory } \\
\text { attribute }\end{array}$ & description & reference sample \\
\hline appearance & $\begin{array}{l}\text { orange } \\
\text { color }\end{array}$ & $\begin{array}{l}\text { the intensity of orange } \\
\text { color }\end{array}$ & \\
\hline \multirow[t]{5}{*}{ aroma } & carrot & aroma of raw carrot root & \\
\hline & terpene & $\begin{array}{l}\text { harsh and turpentine-like } \\
\text { aroma }\end{array}$ & $\begin{array}{l}\text { mixture of authentic } \\
\text { terpene standards }\end{array}$ \\
\hline & green top & aroma of green carrot top & fresh cut carrot top \\
\hline & faded & aroma of faded hay & \\
\hline & soapy & aroma of soap & soft soap \\
\hline \multirow[t]{6}{*}{ flavor } & carrot & flavor of raw carrot root & \\
\hline & terpene & $\begin{array}{l}\text { harsh and turpentine-like } \\
\text { flavor }\end{array}$ & $\begin{array}{l}\text { mixture of authentic } \\
\text { terpene standards }\end{array}$ \\
\hline & green top & flavor of green carrot top & fresh cut carrot top \\
\hline & faded & flavor of faded hay & \\
\hline & soapy & flavor of soap & soft soap \\
\hline & nutty & flavor of green hazelnut & \\
\hline \multirow[t]{2}{*}{ taste } & sweetness & taste of sugar & \\
\hline & bitterness & & \\
\hline aftertaste & burning & $\begin{array}{l}\text { sharp, burning aftertaste } \\
\text { in the mouth }\end{array}$ & \\
\hline texture & juiciness & $\begin{array}{l}\text { sensation of juiciness and } \\
\text { moistness when chewed }\end{array}$ & \\
\hline
\end{tabular}

beakers with lids and coded with three-digit numbers. Samples were evaluated at individual speed on an unstructured $15 \mathrm{~cm}$ line scale with end anchor points ranging from low (value 0 ) to high intensity (value 15 ) in a randomized order to avoid bias. All data were registered on computers using the FIZZ sensory software solution system (ver. $2.00 \mathrm{M}$, Couternon, France).

Statistical Analysis. Statistical analysis was performed using the general linear models (GLM) procedure of the Statistical Analysis 
System (SAS Institute, Cary, NC). Chemical data and root size data were analyzed by two-way analysis of variance (ANOVA) to test for significant differences between cropping system, growing year, and interactions. Sensory data were analyzed each year separately by mixed model ANOVA with cropping system as main effect and assessor as random effect. Data were checked for outliers and normal distribution before statistical analysis. Tukey's honest significance difference (HSD) test was used for multiple comparisons at $P=0.05$, and all conclusions were based on Type III sums of squares for missing data. Principal component analysis (PCA) was performed in SIMCA-P+ (ver. 13.03., Umetrics, Umeå, Sweden) to describe the relation between climate data, root size, and contents of DM, sugars, polyacetylenes, and terpenes. Mean values over field replicates were used. All data were mean-centered and autoscaled before analysis.

\section{RESULTS AND DISCUSSION}

In each of the three growing years, conventional and organic carrots were grown under standardized conditions, ${ }^{1}$ and differences with regard to days to harvest, harvest method, curing, postharvest storage, sampling of carrots for analyses, and sample preparation were kept at a minimum. Only fertilization and pest management practices differed between the cropping systems (Table 1). In the conventional system, inorganic NPK fertilizer was used, while imported pig slurry in the $\mathrm{O} 1$ and an undersown legume/nonlegume mixture were used in the $\mathrm{O} 2$ and $\mathrm{O} 3$ systems. Carrots grown in the $\mathrm{C}$ and $\mathrm{O} 2$ systems had higher nitrate contents than those grown in the $\mathrm{O} 1$ and $\mathrm{O} 3$ systems $^{36}$ which collaborated with a significantly lower $\mathrm{N}$ uptake in carrots grown in the $\mathrm{O} 3$ system. ${ }^{1}$ As carrots were grown using the same cropping systems at the same location each year, it was mainly the climatic conditions which differed between years. The global radiation and the mean air temperature at $2 \mathrm{~m}$ height each month are seen in Figure 1.

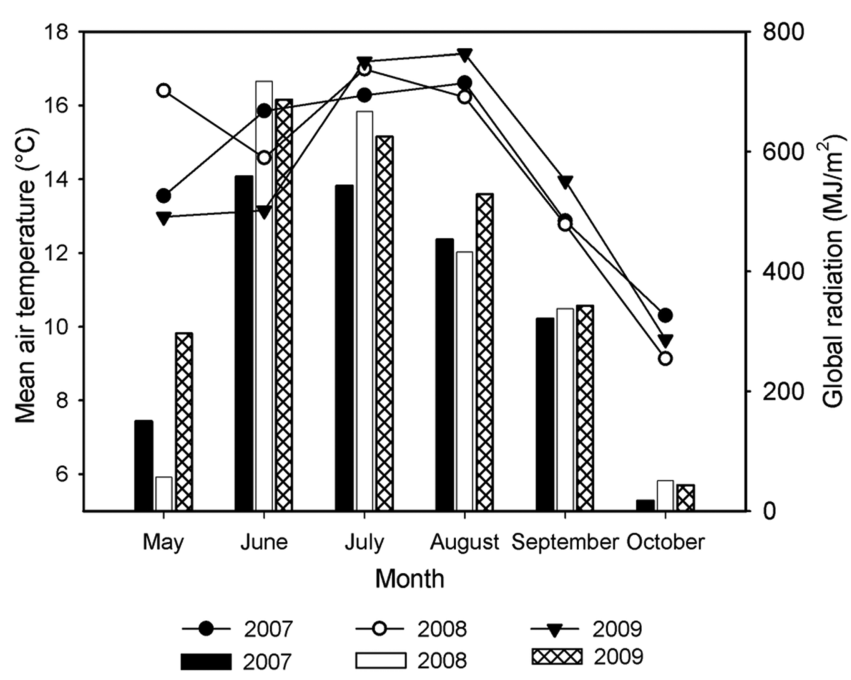

Figure 1. Monthly mean temperature $\left({ }^{\circ} \mathrm{C}\right)$ (lines) and global radiation $\left(\mathrm{MJ} / \mathrm{m}^{2}\right)$ (bars) from sowing in May to harvest in October for carrots grown in 2007, 2008, and 2009.

The results showed significant differences $(P \leq 0.05)$ in root size and in contents of DM, sugars, polyacetylenes, and terpenes between the three growing years (Tables 2, 4, and 5), but no significant differences $(P>0.05)$ between cropping systems for any of the investigated chemical constituents or sensory attributes (Figures 2 and 3).

A PCA was made with the data from all three years to explore the relations between the climate data, the root size, and the chemical constituents (Figure 4). The data from the descriptive sensory analysis were not included in the PCA, as it was not possible to compare the results of the sensory analysis between years because assessors differed and intensity levels could not be standardized. PC 1 explained $65 \%$ of the variation in the data, and PC 2 explained 23\%. The score plot showed that the model only separated the three growing years and not the cropping systems (Figure 4A). PC1 mainly described the differences between year 2009 and the years 2007 and 2008, whereas PC2 explained the difference between the years 2007 and 2008 (Figure 4A).

Root Size. Carrots were harvested 133, 131, and 139 days after sowing in 2007, 2008, and 2009, respectively, and thus with less than a week difference in growing period, and stored for 44, 22, and 30 days, respectively, at $1{ }^{\circ} \mathrm{C}$ before analyses (Table 2). Previous results showed that there was no effect of cropping system on size distribution, root defects, or incidences of pests and diseases within the year. ${ }^{1}$ As root size affects the contents of secondary metabolites, ${ }^{4}$ carrots of similar size were sampled from all cropping systems each year. The carrots were chosen from a representative group of medium-sized carrots ranging between 31 and $41 \mathrm{~mm}$ in diameter and weighing between 75 and $150 \mathrm{~g}$. There were no significant differences $(P$ $>0.05)$ in weight, length, or cylindricity between the sampled carrots from each cropping system within the year (data not shown), but there were significant differences $(P \leq 0.001)$ between years (Table 2). The sampled carrots varied between 87 and $149 \mathrm{~g}$ in weight, 14 to $19 \mathrm{~cm}$ in length (Table 2), and 31 to $39 \mathrm{~mm}$ in root diameter (data not shown) over the three years. Carrots with the highest root weight and length were sampled in 2009, intermediate in 2007, and lowest in 2008 (Table 2). Cylindricity showed an opposite tendency, with the highest value in 2007 and the lowest in 2009 (Table 2). This implies that carrots grown in 2007 were more cylindrical and less conical in shape than those grown in 2009.

Rosenfeld et al. ${ }^{19,20}$ reported that light had a larger effect on root size than on carrot composition (DM, sugars, and carotenoids) and sensory quality, whereas it was opposite for temperature. Carrots grown in phytotrons with peat soil at low temperatures $\left(9\right.$ and $12{ }^{\circ} \mathrm{C}$ ) had longer roots of lower weights than carrots grown at higher temperatures $\left(18\right.$ and $\left.21{ }^{\circ} \mathrm{C}\right)$ at the same solar radiation. ${ }^{19}$ Carrots grown at the same temperature but at higher solar radiation (1385-1395 MJ/ $\mathrm{m}^{2}$ ) were longer and heavier than those grown at lower solar radiation $\left(182 \mathrm{MJ} / \mathrm{m}^{2}\right) .{ }^{20}$ In our study root weights and lengths followed the same trend, as the lightest and shortest roots were harvested in 2008 and the heaviest and longest in 2009 (Table 2 ). The mean air temperature was almost similar the three years (15.1, 14.9, and $15.0^{\circ} \mathrm{C}$ in 2007,2008 , and 2009, respectively), while there were bigger differences in the temperature sum and the global radiation between years. The temperature sum was 1909 , 1937, and 2090 in 2007, 2008, and 2009, respectively, and the global radiation was 2041,2262 , and $2523 \mathrm{MJ} / \mathrm{m}^{2}$ in 2007,2008 , and 2009, respectively.

In Figure 4B, root weight and length were placed together in the loading plot of the PCA and near the temperature sum and the global radiation with regard to $\mathrm{PC} 1$, but opposite to cylindricity. Mean air temperature, on the other hand, had a low influence on PC1, but it influenced the discrimination between the years 2007 and 2008 along PC2 (Figure 4). The higher global radiation and temperature sum of 2009 gave longer and heavier roots with a more conical shape than the lower radiation and temperature sum of 2007 and 2008. This was 
Table 4. Contents of Dry Matter, Sugars, and Polyacetylenes per $100 \mathrm{~g}$ Fresh Weight of Carrot ${ }^{a}$

\begin{tabular}{|c|c|c|c|c|}
\hline \multirow[b]{2}{*}{ compound } & \multicolumn{3}{|c|}{ year } & \multirow[b]{2}{*}{ significance level } \\
\hline & 2007 & 2008 & 2009 & \\
\hline $\begin{array}{l}\text { dry matter }(\mathrm{g} / 100 \mathrm{~g}) \\
\text { sugars }(\mathrm{g} / 100 \mathrm{~g})\end{array}$ & $11.4 \pm 0.2 b^{b}$ & $11.3 \pm 0.2 \mathrm{~b}$ & $13.2 \pm 0.6 a$ & $P \leq 0.001$ \\
\hline glucose & $1.7 \pm 0.1 \mathrm{a}$ & $1.6 \pm 0.1 \mathrm{a}$ & $1.4 \pm 0.1 \mathrm{~b}$ & $P \leq 0.001$ \\
\hline fructose & $1.7 \pm 0.2 \mathrm{a}$ & $1.4 \pm 0.1 \mathrm{~b}$ & $1.3 \pm 0.1 b$ & $P \leq 0.001$ \\
\hline sucrose & $4.5 \pm 0.3 b$ & $4.5 \pm 0.3 b$ & $6.1 \pm 0.5 a$ & $P \leq 0.001$ \\
\hline $\begin{array}{l}\text { total sugars } \\
\text { polyacetylenes }(\mathrm{mg} / 100 \mathrm{~g})\end{array}$ & $7.9 \pm 0.4 b$ & $7.5 \pm 0.2 \mathrm{~b}$ & $8.9 \pm 0.5 \mathrm{a}$ & $P \leq 0.001$ \\
\hline falcarindiol & $3.6 \pm 0.7 \mathrm{ab}$ & $2.9 \pm 0.4 \mathrm{~b}$ & $4.0 \pm 0.8 \mathrm{a}$ & $P \leq 0.01$ \\
\hline falcarinol & $1.3 \pm 0.2 c$ & $2.5 \pm 0.5 b$ & $2.9 \pm 0.5 \mathrm{a}$ & $P \leq 0.001$ \\
\hline falcarindiol-3-acetate & $0.7 \pm 0.3 b$ & $1.0 \pm 0.2 \mathrm{~b}$ & $1.8 \pm 0.6 \mathrm{a}$ & $P \leq 0.001$ \\
\hline total polyacetylenes & $5.5 \pm 1 \mathrm{~b}$ & $6.4 \pm 0.7 b$ & $8.8 \pm 0.5 a$ & $P \leq 0.001$ \\
\hline
\end{tabular}

${ }^{a}$ Data are presented as mean values of the four cropping systems and triplicate samples per system \pm standard deviation $(N=12) .{ }^{b}$ Means followed by different letters in the same row are significantly different according to Tukey's honest significance test at $P=0.05$.

Table 5. Contents of Isolated Terpenes in $\mu \mathrm{g}$ per $100 \mathrm{~g}$ Fresh Weight of Carrot ${ }^{a}$

\begin{tabular}{|c|c|c|c|c|}
\hline \multirow[b]{2}{*}{ volatile compounds ${ }^{b}$} & \multicolumn{3}{|c|}{ year } & \multirow[b]{2}{*}{ significance level $^{c}$} \\
\hline & 2007 & 2008 & 2009 & \\
\hline$\alpha$-pinene & $5.15 \pm 1.72 \mathrm{a}^{d}$ & $3.30 \pm 1.19 b$ & $4.88 \pm 2.01 \mathrm{a}$ & $P \leq 0.01$ \\
\hline$\alpha$-thujene & $1.25 \pm 0.41 \mathrm{a}$ & $0.90 \pm 0.41 \mathrm{a}$ & $0.93 \pm 0.29 \mathrm{a}$ & ns \\
\hline camphene & $0.22 \pm 0.08 \mathrm{a}$ & $0.14 \pm 0.04 b$ & $0.25 \pm 0.09 \mathrm{a}$ & $P \leq 0.001$ \\
\hline$\beta$-pinene & $2.93 \pm 0.52 \mathrm{a}$ & $1.81 \pm 0.56 \mathrm{~b}$ & $1.45 \pm 0.31 b$ & $P \leq 0.001$ \\
\hline sabinene & $11.9 \pm 3.35 b$ & $18.5 \pm 7.33 \mathrm{a}$ & $19.3 \pm 7.01 \mathrm{a}$ & $P \leq 0.05$ \\
\hline$\alpha$-phellandrene & $1.64 \pm 0.67 \mathrm{a}$ & $1.21 \pm 0.67 \mathrm{ab}$ & $0.92 \pm 0.39 \mathrm{~b}$ & $P \leq 0.05$ \\
\hline$\beta$-myrcene & $4.80 \pm 1.57 \mathrm{a}$ & $5.09 \pm 2.56 \mathrm{a}$ & $6.82 \pm 2.19 \mathrm{a}$ & ns \\
\hline$\alpha$-terpinene & $1.58 \pm 0.61 \mathrm{a}$ & $0.67 \pm 0.40 b$ & $0.7 \pm 0.19 b$ & $P \leq 0.001$ \\
\hline limonene & $8.98 \pm 2.98 \mathrm{a}$ & $6.52 \pm 3.09 \mathrm{ab}$ & $5.67 \pm 2.33 b$ & $P \leq 0.05$ \\
\hline$\beta$-phellandrene & $0.58 \pm 0.21 \mathrm{a}$ & $0.33 \pm 0.17 b$ & $0.43 \pm 0.13 \mathrm{ab}$ & $P \leq 0.05$ \\
\hline$\gamma$-terpinene & $37.1 \pm 9.78 \mathrm{a}$ & $19.13 \pm 9.21 b$ & $12.5 \pm 3.37 \mathrm{~b}$ & $P \leq 0.001$ \\
\hline$p$-cymene & $5.31 \pm 0.94 \mathrm{a}$ & $2.08 \pm 0.54 \mathrm{~b}$ & $1.33 \pm 0.2 c$ & $P \leq 0.001$ \\
\hline terpinolene & $131.4 \pm 48.8 \mathrm{a}$ & $86.8 \pm 45.4 b$ & $61.9 \pm 29.2 \mathrm{~b}$ & $P \leq 0.01$ \\
\hline$\beta$-caryophyllene & $41.3 \pm 5.17 \mathrm{a}$ & $27.7 \pm 6.5 b$ & $36.9 \pm 6.31 \mathrm{a}$ & $P \leq 0.001$ \\
\hline$\alpha$-humulene & $1.82 \pm 0.23 \mathrm{a}$ & $1.17 \pm 0.27 c$ & $1.55 \pm 0.26 \mathrm{~b}$ & $P \leq 0.001$ \\
\hline$\beta$-farnesene & $0.40 \pm 0.09 a$ & $0.26 \pm 0.07 \mathrm{~b}$ & $0.43 \pm 0.1 \mathrm{a}$ & $P \leq 0.001$ \\
\hline$\gamma$-bisabolene & $3.29 \pm 0.52 \mathrm{a}$ & $1.63 \pm 0.49 b$ & $3.54 \pm 0.98 \mathrm{a}$ & $P \leq 0.001$ \\
\hline$\beta$-bisabolene & $0.73 \pm 0.2 \mathrm{a}$ & $0.37 \pm 0.1 \mathrm{~b}$ & $0.66 \pm 0.17 \mathrm{a}$ & $P \leq 0.001$ \\
\hline total terpenes & $260.3 \pm 70.3 a$ & $177.6 \pm 76.5 b$ & $160.1 \pm 48.6 b$ & $P \leq 0.01$ \\
\hline
\end{tabular}

${ }^{a}$ Data are presented as mean values of the four cropping systems and triplicate samples per system \pm standard deviation $(N=12) .{ }^{b}$ Identification is based on mass spectra and RI of authentic reference compounds. ${ }^{c}$ ns, not significant. ${ }^{d}$ Means followed by different letters in the same row are significantly different according to Tukey's honest significance test at $P=0.05$.

unexpected as a more progressed growth development and more mature roots are known to give a more cylindric shape of the root. ${ }^{19,22}$

Contents of DM and Sugars. The contents of DM varied between 11.1 and $13.7 \mathrm{~g} / 100 \mathrm{~g}$ fresh weight (FW) (Figure 2). In 2009, the DM and sugar contents were significantly higher $(P \leq 0.05)$ than in 2007 and 2008 (Table 4). In 2007 and 2008, subsamples of carrots were taken from the same fields and sent for analyses at two other research laboratories in Europe. In one laboratory, the DM content of peeled carrots was significantly higher in $2008(11.3 \mathrm{~g} / 100 \mathrm{~g} \mathrm{FW})$ than in 2007 (9.2 g/100 g $\mathrm{FW}){ }^{7}$ while there were no significant differences between years in DM content of unpeeled carrots $(9.5 \mathrm{~g} / 100 \mathrm{~g}$ FW both years) in the other laboratory. ${ }^{36}$ We found no significant differences $(P>0.05)$ between DM contents of carrots grown in 2007 and 2008 (Table 4).

Glucose, fructose, and sucrose were identified as the individual sugars present in the carrots (Table 4). Sucrose was the most abundant sugar constituting 57-69\% of the total sugar content, whereas glucose and fructose composed 16$22 \%$ and $15-22 \%$ of the total, respectively. The glucose and fructose contents were significantly higher $(P \leq 0.001)$ in 2007 and 2008 than in 2009, whereas the opposite was seen for sucrose and total sugars (Table 4). Paoletti et al. ${ }^{7}$ found a lower content of sucrose and fructose in 2008 than in 2007, whereas the glucose content remained the same the two years. In our study there was no difference in the content of glucose and sucrose between 2007 and 2008, but fructose was higher in 2007 than in 2008 . We used carrots in the size range $87-149 \mathrm{~g}$ (Table 2), while Paoletti et al. ${ }^{7}$ used carrots of 50-250 g, and they could therefore have experienced a larger size difference between the two years than us, which might explain the difference in DM and sugar contents.

The contents of DM and total sugars followed the same trend as root weight and length (Table 2), as contents were higher in 2009 than in 2007 and 2008. According to the PCA 


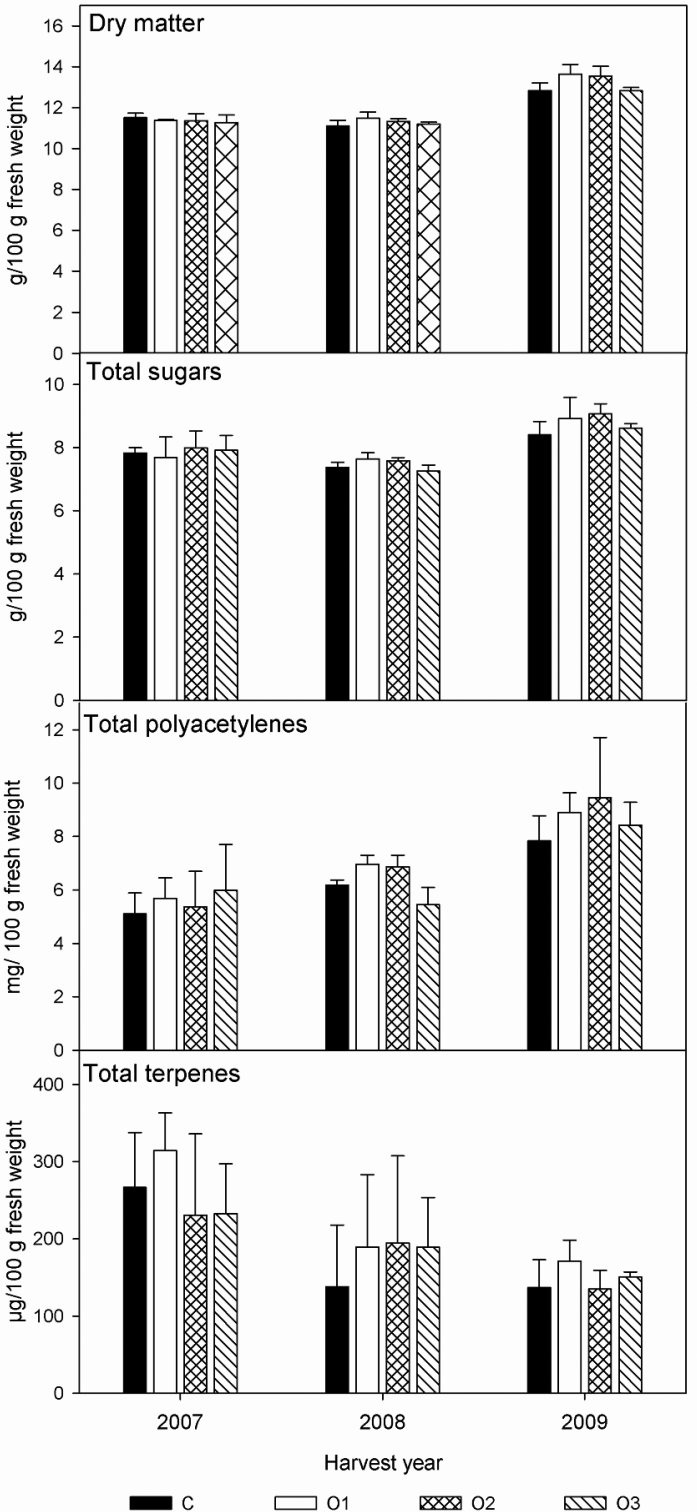

Figure 2. Contents of dry matter, total sugars, total polyacetylenes, and total terpenes in carrots grown in four cropping systems in 2007, 2008, and 2009. Values are mean + standard deviation of three field replicates. There were no significant differences $(P>0.05)$ between cropping systems for any of the constituents. The cropping systems are described in Table 1.

model, the contents of DM, sucrose, and especially total sugars were highly related to temperature sum and global radiation (Figure 4B); i.e., a higher temperature sum and global radiation gave a higher DM, sucrose, and total sugar content of the root. Sucrose was negatively related to glucose and fructose contents as these constituents were placed opposite to each other with regard to PC1 (Figure 4B). Apparently, the sucrose metabolism was up-regulated in 2009 when global radiation and temperature were high, while the metabolism of glucose and fructose was down-regulated. This is consistent with previous results on carrots. $^{2,20,29}$ There was no effect of cropping system on the contents of DM and sugars (Figure 2), despite that the nitrogen supply differed between the systems (Table 1). Neither Paoletti et al. ${ }^{7}$ nor Jensen et al. ${ }^{36}$ found any effect of cropping system on the DM content of carrots grown in 2007 and 2008.
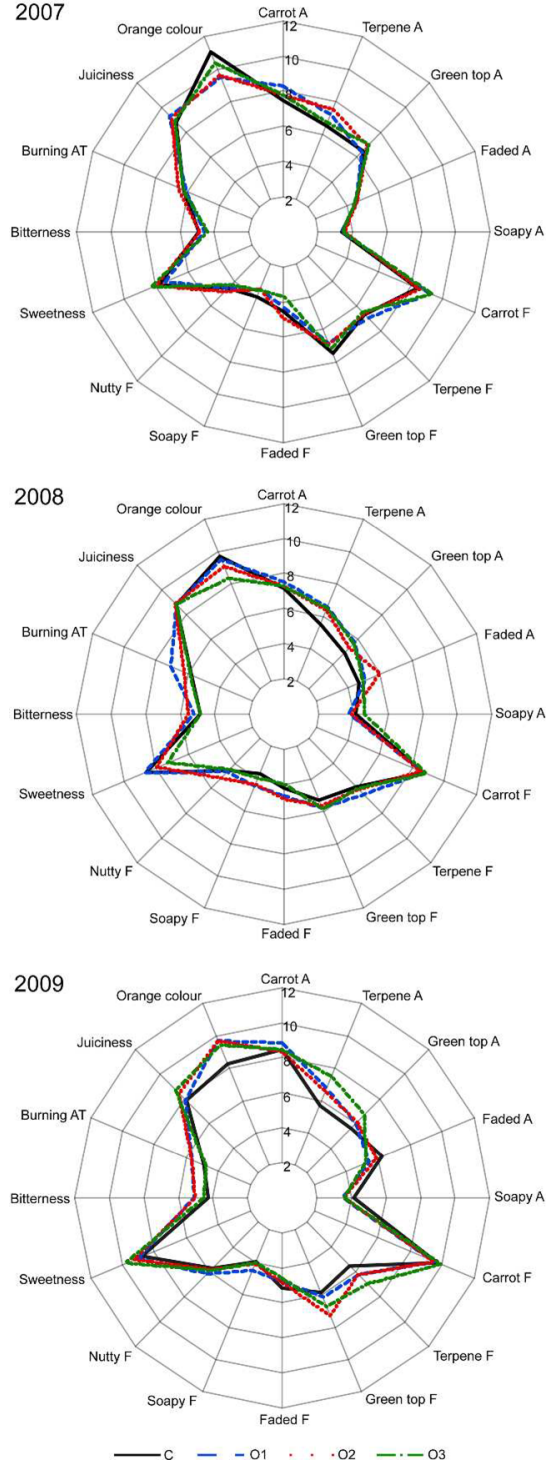

Figure 3. Spiderplots of the descriptive sensory analyses of carrots grown in the four cropping systems in 2007, 2008, and 2009. A, aroma; F, flavor; AT, aftertaste. There were no significant differences $(P>0.05)$ between cropping systems for any of the sensory attributes in any of the years. The cropping systems are described in Table 1.

Polyacetylenes. The polyacetylenes $\mathrm{FaOH}, \mathrm{FaDOH}$, and FaDOAc were quantified in the fresh carrots (Table 4). The contents of total polyacetylenes varied between 5.1 and $9.5 \mathrm{mg} /$ $100 \mathrm{~g} \mathrm{FW}$ (Figure 2), and the contents were thus in line with previous results on cv. Bolero. ${ }^{4,32,37} \mathrm{FaDOH}$ was the most abundant polyacetylene followed by $\mathrm{FaOH}$ and $\mathrm{FaDOAc}$ (Table 4). Søltoft et al. ${ }^{15}$ have previously quantified the polyacetylenes in carrots from cropping systems $\mathrm{C}, \mathrm{O} 1$, and $\mathrm{O} 2$ in 2007 and 2008 relative to $\mathrm{FaDOH}$, and they found a similar relationship between the polyacetylenes as in our study. Others also found that $\mathrm{FaDOH}$ is the most abundant polyacetylene in unpeeled $^{37,38}$ and peeled carrots. ${ }^{4}$

The contents of $\mathrm{FaOH}$ and $\mathrm{FaDOAc}$ and total polyacetylenes were higher in 2009 than in 2007 and 2008, and the content of $\mathrm{FaDOH}$ was higher in 2009 than in 2008 (Table 4). According to Kjellenberg et al., ${ }^{37}$ growing year has a greater effect on the polyacetylene content than harvest date, geographical location, and cultivar. The concentration of total 



Figure 4. PCA plot of the climate data, root size, and chemical constituents of carrots grown in the four cropping systems in 2007, 2008 , and 2009. Data are presented as mean values of the three field replicates. (A) Score plot. (B) Loading plot. The cropping systems are described in Table 1 .

polyacetylenes across growing years followed the same trend as DM and total sugars (Table 4). This can also be seen in Figure $4 \mathrm{~B}$, where $\mathrm{DM}$, total sugars, and total polyacetylenes were placed together in the plot along PC1. As with DM, total sugars, and sucrose, the content of polyacetylenes was higher at high than at low global radiation and temperature sum. The individual polyacetylenes $\mathrm{FaOH}$ and $\mathrm{FaDOAc}$ were positively related to sucrose and negatively related to glucose and fructose, a result which was also supported by significant Pearson correlations (data not shown). FaDOH was placed in the same end of the plot with regard to PC1 but was not correlated to any of the sugar constituents. Kjellenberg et al. ${ }^{22}$ suggested that the sucrose-hydrolyzing enzymes and the enzymes converting $\mathrm{FaOH}$ to $\mathrm{FaDOH}$ and $\mathrm{FaDOAc}$ are active under the same conditions in the carrot. If this was the case $\mathrm{FaDOH}$ and FaDOAc should have been placed near glucose and fructose in Figure $4 \mathrm{~B}$, and not together with $\mathrm{FaOH}$ and sucrose as it was the case.

There were no significant $(P>0.05)$ differences between cropping systems in the content of total polyacetylenes in any of the three years (Figure 2). Polyacetylenes are phytoalexins which are synthesized in the plant as a response to stress conditions such as fungal infection. ${ }^{23}$ In 2007 , there was a high incidence of carrot fly (17.5\%) and cavity spot symptoms (4.3\%) at harvest but not in 2008. ${ }^{39}$ During sampling, carrots with visual symptoms of pests and diseases were discarded and not included in the samples for analyses, and therefore we did not expect to see differences in the polyacetylene contents due to pest and diseases between cropping systems and growing years. This is in line with Søltoft et al. ${ }^{15}$ who reported the same contents of $\mathrm{FaOH}, \mathrm{FaDOH}$, and $\mathrm{FaDOAc}$ in cv. Bolero grown in 2007 and 2008 in the C, O1, and O2 systems.

Terpenes. Eighteen terpenes were identified in the carrots, and the total content varied between $134 \mu \mathrm{g} / 100 \mathrm{~g}$ FW in the $\mathrm{O} 2$ system in 2009 and $314 \mu \mathrm{g} / 100 \mathrm{~g} \mathrm{FW}$ in the $\mathrm{O} 1$ system in 2007 (Figure 2). Terpinolene was the most abundant terpene and $\beta$-caryophyllene and $\gamma$-terpinene the second most abundant terpenes (Table 5). In other studies, terpinolene has also been the main terpene in carrots. ${ }^{26-29}$ Terpinolene comprised 50, 49 , and $39 \%$ and total monoterpenes 82,82 , and $73 \%$ of the total volatiles in 2007, 2008, and 2009, respectively. Sixteen of the individual terpenes and the total content of volatiles were different in the three growing years (Table 5). The total content was higher in 2007 than in 2008 and 2009 (Table 5). The same trend was seen for many of the other terpenes including terpinolene. $\beta$-Caryophyllene, on the other hand, followed another trend as the lowest content was observed in 2008 (Table 5). The monoterpene sabinene was the only terpene which had the lowest content in 2007 (Table 5).

In Figure 4B it is clear that total terpenes is negatively related to total sugars, polyacetylenes, and DM but positively related to fructose and glucose; i.e., terpenes are formed in years with low global radiation and low temperature sum which also favor glucose and fructose synthesis (Figure 4B). Paoletti et al. ${ }^{7}$ found that the contents of total sesquiterpenes and $\beta$ caryophyllene were higher in 2008 than in 2007 in carrots grown in the $\mathrm{C}, \mathrm{O} 1, \mathrm{O} 2$, and $\mathrm{O} 3$ systems. This result is in contrast to our results (Table 5). Paoletti et al. ${ }^{7}$ reported only total sesquiterpenes and $\beta$-caryophyllene, and therefore information is sparse on individual terpenes in relation to growing year. In addition, Paoletti et al. ${ }^{7}$ extracted volatile compounds with water, and then isolated terpenes from the water phase with stir bar sorptive extraction, a method that would result in a low content of volatiles due to the insolubility of the terpenes in the water phase. In our study we used dynamic headspace sampling on Tenax TA traps, which is a gentle method for sampling of sensory important aroma volatiles. As seen with the other chemical compounds, there were no differences in the contents of terpenes between cropping systems (Figure 2).

Sensory Quality. The sensory attributes chosen for descriptive sensory analysis were similar to other studies on sensory quality of fresh carrots. ${ }^{28}$ As seen in Figure 3, the spider plots of all three growing years had similar patterns. However, it was not possible to compare the results of the sensory analysis between years because assessors differed and intensity levels could not be standardized. In each year it was the same sensory attributes which scored highest; carrot flavor, sweetness, juiciness, and orange color.

Terpenes contribute to the characteristic aroma and flavor of carrots such as terpene aroma and flavor, green top aroma and flavor, and burning aftertaste. ${ }^{28}$ Simon et al. ${ }^{29}$ reported that the contribution of terpenes to carrot flavor depends on the sugar content of the carrots, as certain terpenes contribute negatively to sweet taste. Carrots harvested in 2007 had a high content of total terpenes (Table 5) and a low content of sugars (Table 4), 
and they were therefore expected to be stronger in carrot aroma and flavor than carrots from 2009, which had lower terpene contents (Table 5) and higher sugar contents (Table 4). A high sugar content and sweet taste can also mask the contribution of terpenes to harsh flavor and bitterness. ${ }^{28,40}$ Bitterness in carrots may be due to several secondary metabolites such as $\mathrm{FaOOH}$, 6-methoxymellein, and polyphenols. ${ }^{25,32}$

It has previously been reported that carrots grown at higher temperature $\left(14.5^{\circ} \mathrm{C}\right)$ are sweeter and less bitter and score lower in harsh flavors than carrots grown at lower temperature $\left(10.4{ }^{\circ} \mathrm{C}\right) .{ }^{5}$ Carrots grown at higher temperatures (18 and 21 ${ }^{\circ} \mathrm{C}$ ) also score higher in bitter taste and green flavor than carrots grown at lower temperatures $\left(9\right.$ and $\left.12{ }^{\circ} \mathrm{C}\right) .{ }^{19}$ As total sugars, sucrose, total polyacetylenes, and $\mathrm{FaDOH}$ followed the same trend, carrot taste and flavor relied on a complex balance between these compounds as well as the terpenes. The lack of difference between cropping systems in the attribute orange color is supported by Søltoft et al. ${ }^{14}$ who found no difference in the contents of carotenoids in carrots grown in the cropping systems C, O1, and $\mathrm{O} 2$ in 2007 and 2008.

There was no significant difference in sensory quality between cropping systems for any of the investigated attributes (Figure 3), which is in line with the results of the chemical analyses (Figure 2). Haglund et al. ${ }^{12}$ reported that conventional carrots had higher intensity of carrot flavor and were less bitter than organic carrots, but the results in their study were biased due to the use of different carrot cultivars and different geographical locations for growth of carrots.

We showed that carrots can be grown organically and have comparable eating quality to that of conventional carrots, while being produced in a more sustainable way with increased protection of nature, environment, and water resources against pesticides and excess fertilizer. However, the climate during growing influences the eating quality of carrots.

\section{AUTHOR INFORMATION}

\section{Corresponding Author}

*Telephone: +4587 1583 34. Fax: + 45871548 12. E-mail: Merete.edelenbos@food.au.dk.

\section{Funding}

This project was supported by a grant from the International Centre for Research in Organic Food Systems (ICROFS) with the title "Organic Cropping Systems for Vegetable Production-Product Quality, Natural Regulation, and Environmental Effects (VEG-QURE 3304-FOJO-05-45-07)”.

Notes

The authors declare no competing financial interest.

\section{ACKNOWLEDGMENTS}

We thank Jens Michael Madsen, Lone Borum, Birgitte Foged, and Lone Storm for their expert assistance during sampling and sample preparation, as well as for their assistance with HPAEC, HPLC, GC-MS analyses, and sensory training and evaluation. We thank the project leader, Professor Kristian ThorupKristensen, for design of the field experiments and for support throughout the experimental period.

\section{REFERENCES}

(1) Thorup-Kristensen, K.; Dresbøll, D. B.; Kristensen, H. L. Crop yield, root growth, and nutrient dynamics in a conventional and three organic cropping systems with different levels of external inputs and $\mathrm{N}$ re-cycling through fertility building crops. Eur. J. Agron. 2012, 37, 6682.

(2) Hogstad, S.; Risvik, E.; Steinsholt, K. Sensory quality and chemical composition in carrots: A multivariate study. Acta Agric. Scand., Sect. B 1997, 47, 253-264.

(3) Seljåsen, R.; Lea, P.; Torp, T.; Riley, H.; Berentsen, E.; Thomsen, M.; Bengtsson, G. B. Effects of genotype, soil type, year, and fertilisation on sensory and morphological attributes of carrots (Daucus carota L.). J. Sci. Food Agric. 2012, 92, 1786-1799.

(4) Kidmose, U.; Hansen, S. L.; Christensen, L. P.; Edelenbos, M.; Larsen, E.; Nørbæk, R. Effects of genotype, root size, storage, and processing on bioactive compounds in organically grown carrots (Daucus carota L.). J. Food Sci. 2004, 69, S388-S394.

(5) Rosenfeld, H. J.; Risvik, E.; Samuelsen, R. T.; Rødbotten, M. Sensory profiling of carrots from northern latitudes. Food Res. Int. 1997, 30, 593-601.

(6) Brandt, K.; Leifert, C.; Sanderson, R.; Seal, C. J. Agroecosystem management and nutritional quality of plant foods: The case of organic fruits and vegetables. Crit. Rev. Plant Sci. 2011, 30, 177-197.

(7) Paoletti, F.; Raffo, A.; Kristensen, H. L.; Thorup-Kristensen, K.; Seljåsen, R; Torp, T.; Busscher, N.; Ploeger, A.; Kahl, J. Multi-method comparison of carrot quality from a conventional and three organic cropping systems with increasing levels of nutrient recycling. J. Sci. Food Agric. 2012, 92, 2855-2869.

(8) Worthington, V. Nutritional quality of organic versus conventional fruits, vegetables, and grains. J. Altern. Complement. Med. 2001, 7, 161-173.

(9) Bourn, D.; Prescott, J. A comparison of the nutritional value, sensory qualities, and food safety of organically and conventionally produced foods. Crit. Rev. Food Sci. Nutr. 2002, 42, 1-34.

(10) Barański, M.; Średnicka-Tober, D.; Volakakis, N.; Seal, C.; Sanderson, R.; Stewart, G. B.; Benbrook, C.; Biavati, B.; Markellou, E.; Giotis, C.; Gromadzka-Ostrowska, J.; Rembiałkowska, E.; SkwarłoSońta, K.; Tahvonen, R.; Janovská, D.; Niggli, U.; Nicot, P.; Leifert, C. Higher antioxidant and lower cadmium concentrations and lower incidence of pesticide residues in organically grown crops: A systematic literature review and meta-analyses. Br. J. Nutr. 2014, 112, 794-811.

(11) Seljåsen, R.; Kristensen, H. L.; Lauridsen, C.; Wyss, G. S.; Kretzschmar, U.; Birlouez-Aragone, I.; Kahl, J. Quality of carrots as affected by pre- and postharvest factors and processing. J. Sci. Food Agric. 2013, 93, 2611-2626.

(12) Haglund, Å.; Johansson, L.; Berglund, L.; Dahlstedt, L. Sensory evaluation of carrots from ecological and conventional growing systems. Food Qual. Prefer. 1999, 10, 23-29.

(13) Warman, P. R.; Havard, K. A. Yield, vitamin, and mineral contents of organically and conventionally grown carrots and cabbage. Agric., Ecosyst. Environ. 1997, 61, 155-162.

(14) Søltoft, M.; Bysted, A.; Madsen, K. H.; Mark, A. B.; Bügel, S. G.; Nielsen, J.; Knuthsen, P. Effects of organic and conventional growth systems on the content of carotenoids in carrot roots, and on intake and plasma status of carotenoids in humans. J. Sci. Food Agric. 2011, 91, 767-775.

(15) Søltoft, M.; Eriksen, M. R.; Träger, A. W. B.; Nielsen, J.; Laursen, K. H.; Husted, S.; Halekoh, U.; Knuthsen, P. Comparison of polyacetylene content in organically and conventionally grown carrots using a fast ultrasonic liquid extraction method. J. Agric. Food Chem. 2010, 58, 7673-7679.

(16) Varming, C.; Jensen, K.; Møller, S.; Brockhoff, P. B.; Christiansen, T.; Edelenbos, M.; Bjørn, G. K.; Poll, L. Eating quality of raw carrots-correlations between flavour compounds, sensory profiling analysis and consumer liking test. Food Qual. Prefer. 2004, 15, 531-540.

(17) Smolén, S.; Sady, W. The effect of various nitrogen fertilization and foliar nutrition regimes on the concentration of sugars, carotenoids, and phenolic compounds in carrot (Daucus carota L.). Sci. Hortic. 2009, 120, 315-324. 
(18) Schaller, R. G.; Schnitzler, W. H. Nitrogen nutrition and flavour compounds of carrots (Daucus carota L) cultivated in Mitscherlich pots. J. Sci. Food Agric. 2000, 80, 49-56.

(19) Rosenfeld, H. J.; Samuelsen, R. T.; Lea, P. The effect of temperature on sensory quality, chemical composition, and growth of carrots (Daucus carota L.) I. Constant diurnal temperature. J. Horticult. Sci. Biotechnol. 1998, 73, 275-288.

(20) Rosenfeld, H. J.; Samuelsen, R. T.; Lea, P. The effect of temperature on sensory quality, chemical composition, and growth of carrots (Daucus carota L.). II. Constant diurnal temperatures under different seasonal light regimes. J. Horticult. Sci. Biotechnol. 1998, 73, $578-588$.

(21) Kaack, K.; Nielsen, M.; Christensen, L. P.; Thorup-Kristensen, K. Nutritionally important chemical constituents and yield of carrot (Daucus carota L.) roots grown organically using ten levels of green manure. Acta Agric. Scand., Sect. B 2001, 51, 125-136.

(22) Kjellenberg, L.; Johansson, E.; Gustavsson, K.-E.; Olsson, M. E. Polyacetylenes in fresh and stored carrots (Daucus carota): relations to root morphology and sugar content. J. Sci. Food Agric. 2012, 92, 17481754.

(23) Christensen, L. P.; Brandt, K. Bioactive polyacetylenes in food plants of the Apiaceae family: Occurrence, bioactivity and analysis. $J$. Pharm. Biomed. Anal. 2006, 41, 683-693.

(24) Roman, M.; Baranski, R.; Baranska, M. Nondestructive Raman analysis of polyacetylenes in Apiaceae vegetables. J. Agric. Food Chem. 2011, 59, 7647-7653.

(25) Czepa, A.; Hofmann, T. Structural and sensory characterization of compounds contributing to the bitter off-taste of carrots (Daucus carota L.) and carrot puree. J. Agric. Food Chem. 2003, 51, 3865-3873.

(26) Alasalvar, C.; Grigor, J. M.; Zhang, D.; Quantick, P. C.; Shahidi, F. Comparison of volatiles, phenolics, sugars, antioxidant vitamins, and sensory quality of different colored carrot varieties. J. Agric. Food Chem. 2001, 49, 1410-1416.

(27) Kjeldsen, F.; Christensen, L. P.; Edelenbos, M. Quantitative analysis of aroma compounds in carrot (Daucus carota L.) cultivars by capillary gas chromatography using large-volume injection technique. J. Agric. Food Chem. 2001, 49, 4342-4348.

(28) Kreutzmann, S.; Thybo, A. K.; Edelenbos, M.; Christensen, L. P. The role of volatile compounds on aroma and flavour perception in coloured raw carrot genotypes. Int. J. Food Sci. Technol. 2008, 43, $1619-1627$.

(29) Simon, P. W.; Peterson, C. E.; Lindsay, R. C. Correlations between sensory and objective parameters of carrot flavour. J. Agric. Food Chem. 1980, 28, 559-562.

(30) Crawford, R. J.; Erman, W. F.; Broaddus, C. D. Metalation of limonene. A novel method for the synthesis of bisabolene sesquiterpenes. J. Am. Chem. Soc. 1972, 94, 4298-4306.

(31) Bleasdale, J. K. A.; Thompson, R. An objective method of recording and comparing the shapes of carrot roots. J. Hortic. Sci. 1963, $38,232-241$.

(32) Kreutzmann, S.; Christensen, L. P.; Edelenbos, M. Investigation of bitterness in carrots (Daucus carota L.) based on quantitative chemical and sensory analyses. LWT - Food Sci. Technol. 2008, 41, 193-205.

(33) Bach, V.; Kidmose, U.; Bjørn, G. K.; Edelenbos, M. Effects of harvest time and variety on sensory quality and chemical composition of Jerusalem artichoke (Helianthus tuberosus L.) tubers. Food Chem. 2012, 133, 82-89.

(34) ISO 8586-1, General guidance for the selection, training and monitoring of assessors. International Organization for Standardization, Geneva, Switzerland, 1993.

(35) ASTM 913, S. T. P., Physical requirement guidelines for sensory evaluation laboratories. American Society for Testing Materials, Philadelphia, PA, 1986.

(36) Jensen, M. M.; Jørgensen, H.; Halekoh, U.; Watzl, B.; ThorupKristensen, K.; Lauridsen, C. Health biomarkers in a rat model after intake of organically grown carrots. J. Sci. Food Agric. 2012, 92, 29362943.
(37) Kjellenberg, L.; Johansson, E.; Gustavsson, K. E.; Olsson, M. E. Effects of harvesting date and storage on the amounts of polyacetylenes in carrots. J. Agric. Food Chem. 2010, 58, 11703-11708.

(38) Purup, S.; Larsen, E.; Christensen, L. P. Differential effects of falcarinol and related aliphatic $\mathrm{C}_{17}$-polyacetylenes on intestinal cell proliferation. J. Agric. Food Chem. 2009, 57, 8290-8296.

(39) Louarn, S.; Nawrocki, A.; Edelenbos, M.; Jensen, D. F.; Jensen, O. N.; Collinge, D. B.; Jensen, B. The influence of the fungal pathogen Mycocentrospora acerina on the proteome and polyacetylenes and 6methoxymellein in organic and conventionally cultivated carrots (Daucus carota) during post-harvest storage. J. Proteomics 2012, 75, 962-977.

(40) Beck, T. K.; Jensen, S.; Bjørn, G. K.; Kidmose, U. Sucrose influences perception of bitter compounds in Brassica vegetables and bitterness in cabbage. J. Sens. Stud. 2014, 29, 190-200. 